\title{
PERBANDINGAN PEMANFAATAN LOKET, WEBSITE DAN E-BILLING DI PT. MUSTIKA ALAM LESTARI TAHUN 2016 - 2017
}

\author{
Winoto Hadi ${ }^{1}$, Farah Faridah Robbaniyah ${ }^{2}$ \\ Prodi D III Transportasi, Fakultas Teknik - UNJ \\ 2 Prodi D III Transportasi, Fakultas Teknik - UNJ
}

\begin{abstract}
Abstrak. Laporan tugas akhir ini bertujuan untuk mengetahui bagaimana hasil perbandingan dari pemanfaatan loket, website dan E-Billing di PT. Mustika Alam Lestari di tahun 2016 dan tahun 2017, sekaligus sebagai persyaratan kelulusan program studi Manajemen Pelabuhan Universitas Negeri Jakarta. Untuk dapat menyusun tugas akhir ini, penulis mengumpulkan data dalam bentuk primer yaitu berupa hasil kuisioner yang dibagikan kepada para pelanggan PT. Mustika Alam Lestari mengenai sistem loket, terutama website dan E-Billing yang baru berjalan 2 tahun. Proses tersebut dilakukan penulis selama melakukan kegiatan praktik kerja lapangan. Data yang didapatkan kemudian dianalisis dan di jadikan bahan perbandingan dengan data yang sudah ada di tahun 2016. Perkembangan yang ada pada sistem akan berdampak kepada kepuasan pelanggan dan juga kemajuan dari PT. Mustika Alam Lestari. semakin baik sistem berbasis online berjalan, semakin banyak pula pelanggan akan merasa puas dengan pelayanan yang diberikan oleh perusahaan. Tetapi itu semua tidak terlepas dari berbagai kendala. Setelah penulis menganalisis permasalahan ini lebih jauh, penulis akan berusaha memberikan solusi terbaik untuk memecahkan masalah tersebut.
\end{abstract}

Kata kunci : perbandingan, pemanfaatan, sistem, pelayanan pelanggan

\section{A. PENDAHULUAN}

Saat ini, Indonesia sedang mengalami perkembangan dalam bidang transportasi laut khususnya petikemas. Salah satunya adalah pelabuhan petikemas di Tanjung Priok. Terminal - terminal petikemas di Tanjung Priok sudah sangat padat dengan tumpukan kontainer. Pada tahun 2017 terminal petikemas di Tanjung Priok mampu menampung hingga 7 juta TEUs di bandingkan pada tahun sebelumnya yang hanya menampung 5 juta TEUs. Oleh karena itu, pihak terminal perlu mencari solusi agar kegiatan bongkar dan muat kontainer di Tanjung Priok selalu berjalan lancar dengan sasaran mutu yang ditetapkan ISO (International Standart Organization).

Salah satu terminal petikemas yang ada di Tanjung Priok adalah PT. Mustika Alam Lestari yang terletak pada terminal operasi tiga. PT. Mustika Alam Lestari merupakan terminal petikemas sekaligus tempat penumpukan sementara untuk kontainer yang akan di ekspor dan impor sejak tahun 2004. Dengan luas lahan kurang lebih 5 Hektar, memiliki draft sedalam 12 meter, dan panjang dermaga 258 meter, serta kapasitas lapangan 6.000 TEUs. PT. Mustika Alam Lestari juga menerapkan sistem Manajemen Mutu ISO 9001:2008 sejak Oktober 2006.

PT. Mustika Alam Lestari juga merupakan anak perusahaan dari Nusantara Pelabuhan Handal Tbk(PORT), PT Nusantara Pelabuhan Handal, Tbk (NPH) didirikan pada Desember 2003 dengan nama PT Kharisma Mutiara Agung (KMA). Perusahaan mulai mengelola terminal petikemas internasional melalui PT Mustika Alam Lestari (MAL) pada 2004. Selain pelayanan kegiatan bongkar dan muat, PT. Mustika Alam Lestari juga memiliki pelayanan billing dan loket untuk para EMKL (Ekspedisi Muatan Kapal Laut). Billing dan loket yang memiliki fungsi untuk melayani pelanggan dalam kegiatan dokumen kontainer serta administrasi di PT. Mustika Alam Lestari ini juga masih banyak di keluhkan oleh para petugas EMKL.

Pada tahun 2014, PT. Mustika Alam Lestari sudah menambah jumlah petugas loket, akan tetapi tahun 2015 dan 2016 masih banyak mendapatkan keluhan dari petugas EMKL bahwa pelayanan pelanggan untuk loket masih kurang. Maka dari itu, tahun 2016 PT. Mustika Alam Lestari membuat alternatif untuk melakukan administrasi secara online melalui E-Billing online. Tetapi alternatif ini pun juga memiliki kekurangan. Sampai tahun 2017, E-Billing online masih bisa dibilang cukup sulit untuk di gunakan olah petugas EMKL. Terlihat dari masih banyaknya petugas EMKL yang masih menggunaka loket manual untuk melakukan kegiatan penginputan data impor ekspor maupun pembayaran. Selama kurang lebih 2 tahun PT. Mustika Alam Lestari melaksanakan program E-Billing online, dan belum terlihat adanya kenaikan presentase kemajuan yang ditunjukan dari pihak EMKL selaku pengguna $E$-Billing online.

\section{B. METODE PENELITIAN}

Untuk memperoleh data yang akurat, peneliti mengambil sampling sebanyak 10\% dari total pelanggan di PT. Mustika Alam Lestari yang kurang lebih berjumlah 400. Survey yang dilakukan dengan menggunakan angket berisi 8 pertanyaan seputar kegiatan pelayanan loket, website, dan E-Billing. Angket ini dibuat dengan tujuan untuk memperoleh informasi dan juga membandingkan perkembangan loket, website, dan E-Billing dari tahun 2016 ke tahun 2017. Dan juga sejauh mana pelanggan mengetahui atau memanfaatkan fasilitas E-Billing di PT.Mustika Alam Lestari. Survey dilaksanakan pada tanggal 29 Januari 2018 sampai dengan 2 Februari 2018 dengan jumlah responden 40 orang 
yang berada di loket PT. Mustika Alam Lestari, Tanjung Priok Jakarta Utara. Di bawah ini merupakan kisi-kisi dari kuisioner dan juga hasil survey yang dilakukan peneliti di PT. Mustika Alam Lestari tahun 2017.

\section{KERANGKA BERFIKIR}

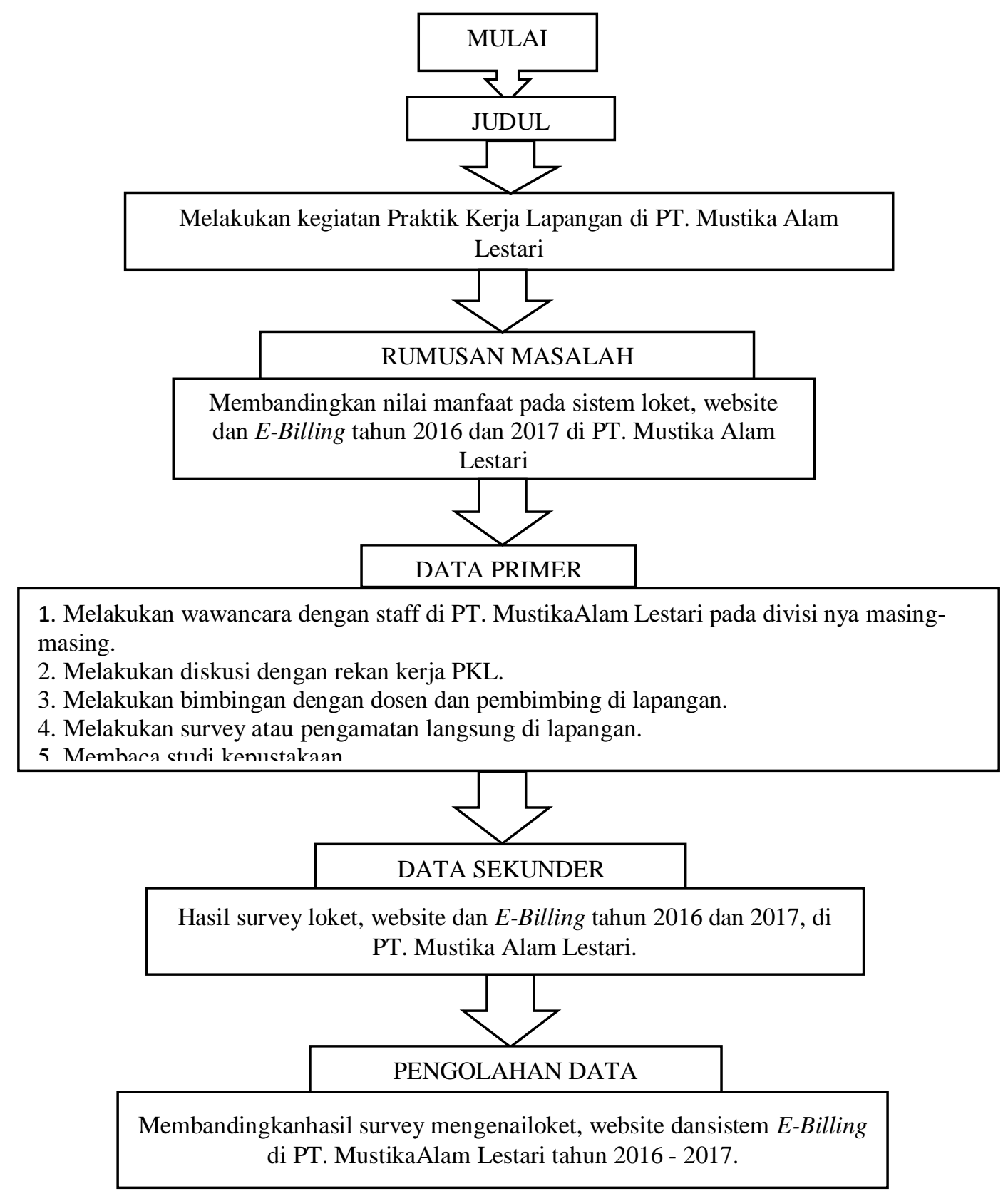

\section{PEMBAHASAN}

Faktor yang menyebabkan permasalahan pelayanan PT Mustika Alam Lestari dibagi dalam dua faktor besar yaitu faktor internal perusahaan dan faktor eksternal perusahaan.

\section{Faktor Internal :}

a) Sistem/Software

Sistem merupakan faktor penting bagi perusahaan. Sistem yang semakin berkembang akan mempengaruhi kemajuan suatu perusahaan. Suatu sistem akan berhasil berjalan apabila cara penggunaan yang mudah di akses dan tidak mempersulit penggunanya. Dari hasil survey yang telah dilakukan oleh peneliti pada tahun 2017 dengan jumlah responden sebanyak 40, 38\% menyatakan tampilan dari E-Billing online di PT. Mustika Alam Lestari masih membingungkan. Tetapi angka persentase tersebut menunjukkan bahwa adanya peningkatan jika dibandingkan dari tahun 2016 yang memiliki angka 57\%. 
b) Sumber Daya Manusia

Sistem tidak akan dapat berjalan sesuai keinginan jika tidak di dukung dengan sumber daya manusia yang baik. Sistem merupakan sebuah sarana, sedangkan sumber daya manusia yang tetap mengatur kinerja dalam sistem di sebuah perusahaan. Jika pihak perusahaan tidak memberikan pelatihan yang baik bagi pegawai, hal ini berdampak kepada kemajuan perusahaan dan kinerja yang berbasis sistem. Dan juga pegawai akan membimbing pelanggan untuk memahami cara penggunaan sistem E-Billing online. Maka dari itu, sangat diperlukannya sikap kerjasama antar perusahaan, pegawai, dan staff IT agar menjadikan sistem loket, website dan E-Billing Online ini menjadi lebih maju dan efektif dalam memperlancar kinerja pelayanan terhadap pelanggan di PT. Mustika Alam Lestari.

c) Kebijakan Perusahaan

Kebijakan yang diterapkan di PT. Mustika Alam Lestari pada awal peluncuran tahun 2016, sistem EBilling online masih belum aktif untuk digunakan. Jika pada saat itu kebijakan dibuat lebih mengarah kepada kinerja E-Billing, pelanggan akan terbiasa dalam menggunakan sistem secara online.

Tetapi jika dilihat dari angka persentase tampilan E-Billing yang meningkat dari 8\% di tahun 2016 menjadi 25\% di tahun 2017 dengan kategori sangat mudah, E-Billing dikatakan berhasil di tahun pertama pengoperasian. Dengan kebijakan PT. Mustika Alam Lestari yang lebih memperhatikan pelayanan pelanggan terutama berbasis sistem.

\section{Faktor Eksternal :}

a) Kerjasama Pelanggan

Pelanggan merupakan faktor penting dalam sistem E-Billing. Sistem tidak akan berguna jika tidak ada pelanggan yang menggunakan sistem tersebut. PT. Mustika Alam Lestari harus bisa menjalin kerjasama yang baik dengan mitra perusahaan. Kelebihan dari sistem E-Billing sebenarnya sangat bermanfaat bagi pelanggan jika dapat tersampaikan dengan cara yang baik. Pelanggan dapat dimana saja dan kapan saja mengakses sistem E-Billing online, serta melakukan pembayaran dengan aman tanpa perlu datang dan membawa sejumlah uang dengan nominal besar. Saat ini, sudah banyak dari pelanggan yang mengerti keunggulan dari sistem E-Billing, walaupun masih ada pelanggan yang datang ke perusahaan dan melakukan transaksi di lokasi. Selain itu, PT. Mustika Alam Lestari akan terus meningkatkan komunikasi yang baik dengan mitra perusahaan.

b) Dampak Permasalahan

PT. Mustika Alam lestari sudah memiliki sistem dan sumber daya manusia yang cukup baik di tahun 2017. Tetapi masih ada kendala yang di rasakan oleh pelanggan dalam penggunaan sistem. Keluhan yang dirasakan oleh pelanggan adalah pada sistem E-Billing online yang terkadang mengalami error pada bagian transaksi yang menggunakan mesin EDC (electronic data capture), khususnya pelanggan yang menggunakan bank mandiri. Hal ini berdampak pada loket 2 yang menangani pembayaran secara manual, tetapi pelanggan tetap harus melanjutkan menginput data melaui sistem E-Billing secara online.

Selain itu, kurangnya komunikasi untuk memasarkan cara penggunaan sistem E-Billing online membuat para pelanggan terutama pelanggan baru merasa bingung dengan tahapan penggunaan sistem yang ada di PT. Mustika Alam Lestari. Hal ini juga berdampak kepada pelanggan yang lebih memilih untuk menggunakan loket secara manual dengan bantuan petugas untuk menginput data ke dalam sistem.

\section{E. KESIMPULAN}

Berdasarkan pengamatan dan hasil survei menggunakan kuisioner, didapatkan kesimpulan sebagai berikut:

1) Aktifitas loket saat ini masih dapat di katakan belum memiliki perubahan yang signifikan dari tahun 2016. Menurut hasil survey tahun 2017 sekitar 14\% dari 40 responden menyatakan kurang puas terhadap loket dan $3 \%$ menyatakan tidak puas dengan pelayanan loket yang masih belum mencapai maksimal. Hal ini disebabkan karena loket yang masih berbasis manual atau dikelola oleh para pegawai PT. Mustika Alam Lestari.

2) Untuk sistem E-Billing online dapat dikatakan cukup baik di tahun 2017. Ini merupakan tahun pertama pengoperasian E-Billing. Walaupun masih ada beberapa penyebab seperti sistem terkadang error EDC (electronic data capture) untuk transaksi melalui bank mandiri, tetapi pelanggan sudah mulai membiasakan untuk mengakses E-Billing online serta masih banyak yang harus datang ke PT. Mustika Alam Lestari. Dan Pihak PT. Mustika Alam Lestari akan terus bekerja untuk memperbaiki kekurangan sistem. Selain itu, mitra bank untuk kegiatan transaksi pembayaran sudah bertambah yang tadinya hanya ada Bank Permata dan sekarang sudah bekerja sama dengan Bank Mandiri dan juga Bank Danamond.

3) Kurangnya penyuluhan informasi mengenai cara penggunaan dan manfaat E-Billing untuk pelanggan. Sehingga membuat para pelanggan masih ragu dalam mengakses sistem E-Billing berbasis online, karena takut akan berdampak kerugian terhadap pelanggan itu sendiri. 
4) Untuk tahun 2017, kinerja loket, website dan E-Billing online masih memiliki kekurangan. Tetapi, pihak PT. Mustika Alam Lesatri tidak akan berhenti untuk memaksimalkan sistem yang dimiliki terutama sistem berbasis online. Sehingga di waktu yang mendatang, perusahaan ini bisa lebih bersaing dengan perusahaan lainnya.

\section{F. SARAN}

Berdasarkan uraian diatas penulis memberikan beberapa saran yang mungkin dapat menjadi bahan pertimbangan oleh PT. Mustika Alam Lestari kedepannya, untuk melakukan peningkatan sistem E-Billing, antara lain :

1) PT. Mustika Alam Lestari perlu menambah jumlah mitra bank lebih banyak untuk transaksi pembayaran oleh pelanggan.

2) Membuat kebijakan mengenai aktivitas penggunaan E-Billing diperusahaan untuk menggantikan sistem loket manual.

3) Melakukan aktivitas pemasaran mengenai sistem E-Billing, baik melaui spanduk, iklan, atau beruba video tutorial penggunaan E-Billing disekitar area loket dan website PT. Mustika Alam Lestari.

4) Melakukan perbaikan tampilan E-Billing dan website, agar lebih menarik dan mudah digunakan oleh pelanggan.

\section{G. DAFTAR PUSTAKA}

Anonim. Pengertian Ekspor dan Impor. https://andriantochandra25.wordpress.com/2012/11/01/pengertian-ekspor danimpor/ (diakses pada tanggal 10 Juli 2018).

Anonim. Pengertian Pelayanan. http://Wikipedia/BahasaIndonesia.com (diakses pada tanggal 20 Mei 2018).

Anonim. Pengertian Pelayanan/Service. http://www.pelajaran.co.id/2017/17/pengertian-pelayanan-menurut-ahli faktor serta-fungsi-dan-tujuan-pelayanan-terlengkap.html (diakses pada tanggal 2 Juli 2018).

Anonim. Pengertian Sistem. https://www.scribd.com/doc/135307007/Pengertian-Sistem-Menurut Indrajit (diakses pada tanggal 2 Juli 2018).

Nugroho. Adi. E-Commerce: Memahami Perdagangan Modern di Dunia Maya. Bandung : Informatika Bandung, 2006.

PT. Mustika Alam Lestari. Billing Service SOP PT. Mustika Alam Lestari. http://nusantaraport.id (diakses pada tanggal 20 Mei 2018).

Suyono, Capt. R. P. Shipping :Pengangkutan Intermodal Ekspor Impor Melalui Laut. Edisi keempat, Jakarta: PPM, 2005. 